Institute of $\mathbf{F}_{\text {ood and }} \mathbf{A}_{\text {gricultural }} \mathbf{S}_{\text {ciences }}$

\title{
Rove Beetles of the World, Staphylinidae (Insecta: Coleoptera: Staphylinidae) ${ }^{1}$
}

J. Howard Frank and Michael C. Thomas ${ }^{2}$

\section{Introduction}

The family Staphylinidae belongs to the suborder Polyphaga of the order Coleoptera (beetles). The superfamily Staphylinoidea includes the small families Hydraenidae, Ptiliidae, Agyrtidae, Leiodidae, Scydmaenidae, and Silphidae, and the huge family Staphylinidae.

SUBORDER Polyphaga -

SUPERFAMILY Staphylinoidea -

FAMILY Staphylinidae

At present, more species of beetles are known than of any other insect order. As now constituted, Staphylinidae are one of the largest families of beetles, with over 45,000 species known worldwide and probably over $75 \%$ of tropical species still undescribed. It is the largest family in the British Isles and in America north of Mexico, and it may prove to be so in other regions when huge numbers of now-unknown species are described (if they are described before they become extinct by habitat destruction). In the future, systematists may, however, choose to split the family into four phyletic lines to form four families. This document takes a worldwide perspective, emphasizing the role of the extremely few species that have been studied; identification is far beyond the scope of this document because of the size of the family.

\section{Classification}

\section{Phylogeny}

Four phyletic lines are now (Lawrence and Newton 1995) included in Staphylinidae:

- subfamilies Glypholomatinae, Microsilphinae, Omaliinae, Empelinae, Proteininae, Micropeplinae, Neophoninae, Dasycerinae, Protopselaphinae, and Pselaphinae;

- subfamilies Phloeocharinae, Olisthaerinae, Tachyporinae, Trichophyinae, Habrocerinae, and Aleocharinae;

- subfamilies Trigonurinae, Apateticinae, Scaphidiinae, Piestinae, Osoriinae, and Oxytelinae;

1. This document is EENY-114, one of a series of Featured Creatures from the Entomology and Nematology Department, Florida Cooperative Extension Service, Institute of Food and Agricultural Sciences, University of Florida. Published: September 1999. Revised: March 2002. This document is also available on Featured Creatures Website at http://creatures.ifas.ufl.edu. Please visit the EDIS Website at http://edis.ifas.ufl.edu. Additional information on these organisms, including many color photographs, is available at the Entomology and Nematology Department website at http://entnemdept.ifas.ufl.edu/.

2. J. Howard Frank, professor, Entomology and Nematology Department, University of Florida, Gainesville, FL, and Michael C. Thomas, Florida Department of Agriculture and Consumer Services, Division of Plant Industry, Gainesville, FL.

The Institute of Food and Agricultural Sciences is an equal opportunity/affirmative action employer authorized to provide research, educational information and other services only to individuals and institutions that function without regard to race, color, sex, age, handicap, or national origin. For information on obtaining other extension publications, contact your county Cooperative Extension Service office. Florida Cooperative Extension Service/Institute of Food and Agricultural Sciences/University of Florida/Christine Taylor Waddill, Dean. 
- subfamilies Oxyporinae, Megalopsidiinae, Steninae, Euaesthetinae, Solieriinae, Leptotyphlinae, Pseudopsinae, Paederinae, and Staphylininae.

The former taxa Brathinidae (now just part of subfamily Omaliinae), Dasyceridae (now subfamily Dasycerinae), Empelidae (now subfamily Empelinae), Glypholomatini (formerly a tribe of Silphidae), Microsilphinae (formerly a subfamily of Silphidae), Pselaphidae (now subfamily Pselaphinae), and Scaphidiidae (now subfamily Scaphidiinae) of earlier authors are here in Staphylinidae.

\section{Fossils}

Pleistocene fossil Staphylinidae have been reported from peat bogs in northeastern North America and from Europe. They seem to be of extant species and help to show former distribution of some of these species. Oligocene fossils are from amber from the Baltic, the Dominican Republic, and elsewhere, and from shales in the USA (Colorado), France, Germany, and elsewhere. Most of these are recognizably members of modern genera. Deposits from the mid-Cretaceous to lower Jurassic in Eurasia have also yielded fossils. Most of these resemble members of modern subfamilies. The oldest recorded staphylinid, more than 200 million years old, is from the upper Triassic of the USA (Virginia).

Species-level identification of present-day staphylinids normally requires dissection, at least of the genitalia - when this cannot be done with fossil specimens they have limited value.

\section{Appearance}

\section{Adults}

The length of adult Staphylinidae ranges from less than $1 \mathrm{~mm}$ to $40 \mathrm{~mm}$. Most are under $7 \mathrm{~mm}$ long. Most have short elytra, exposing several abdominal segments, but it would be an error to imagine that all have short elytra, or that all beetles with short elytra are Staphylinidae. Typically, they are slender with short elytra and powerful abdominal musculature that renders them very flexible, thus able to enter narrow crevices. Those that have short elytra trade flexibility for exposure, rendering them subject to desiccation and dependent upon humid habitats. Abdominal segments are surrounded by sclerotized plates (a large dorsal plate called a tergite, a large ventral plate called a sternite, and up to two pairs of dorso-lateral plates called paratergites) with membranous connections. In some genera (e.g., of Paederinae, Euaesthetinae, and Osoriinae, and partially so in Steninae) the tergites-paratergites-sternites are fused into rings around each segment, probably limiting water loss. The length of adults, which is nevertheless normally used to express size, is an inaccurate determinant of size because abdominal segments typically can be telescoped, making the body appear longer when under moist conditions and alive, but shorter when dried and dead. Eyelessness has evolved in some soil-inhabiting (Leptotyphlinae) and cave-inhabiting species, and winglessness in species occupying environments including mountains, the soil, caves, and seashores.

Non-entomologists sometimes confuse Staphylinidae with Dermaptera. However, the non-opposable valvulae (appendages of the 9th abdominal segment) are not the opposable forcipes of Dermaptera, and the radial wing-folding pattern of Dermaptera is unlike that of Staphylinidae.

\section{Immature Stages}

Staphylinid eggs typically are white, spherical, spheroidal, or pyriform (pear-shaped). Eggs of some genera in the Staphylininae (e.g., Philonthus) have pronounced surface sculpture, allowing identification at least to the species-group level. Larvae are campodeiform (sometimes called staphyliniform). In some subfamilies (Paederinae, Staphylininae, and to a lesser extent in their immediate relatives) the head is relatively more heavily sclerotized and there is a distinct "neck" (nuchal constriction of the head). Prepupae of Steninae, at least most Aleocharinae, and Astenus (Paederinae) spin a silken cocoon in which they pupate. Pupae are obtect, pigmented, and sclerotized in the subfamily Staphylininae, but exarate, white, and unsclerotized in all the other subfamilies. In general, the immature stages develop rapidly, in a few days to a few weeks, and the adults are long-lived. 

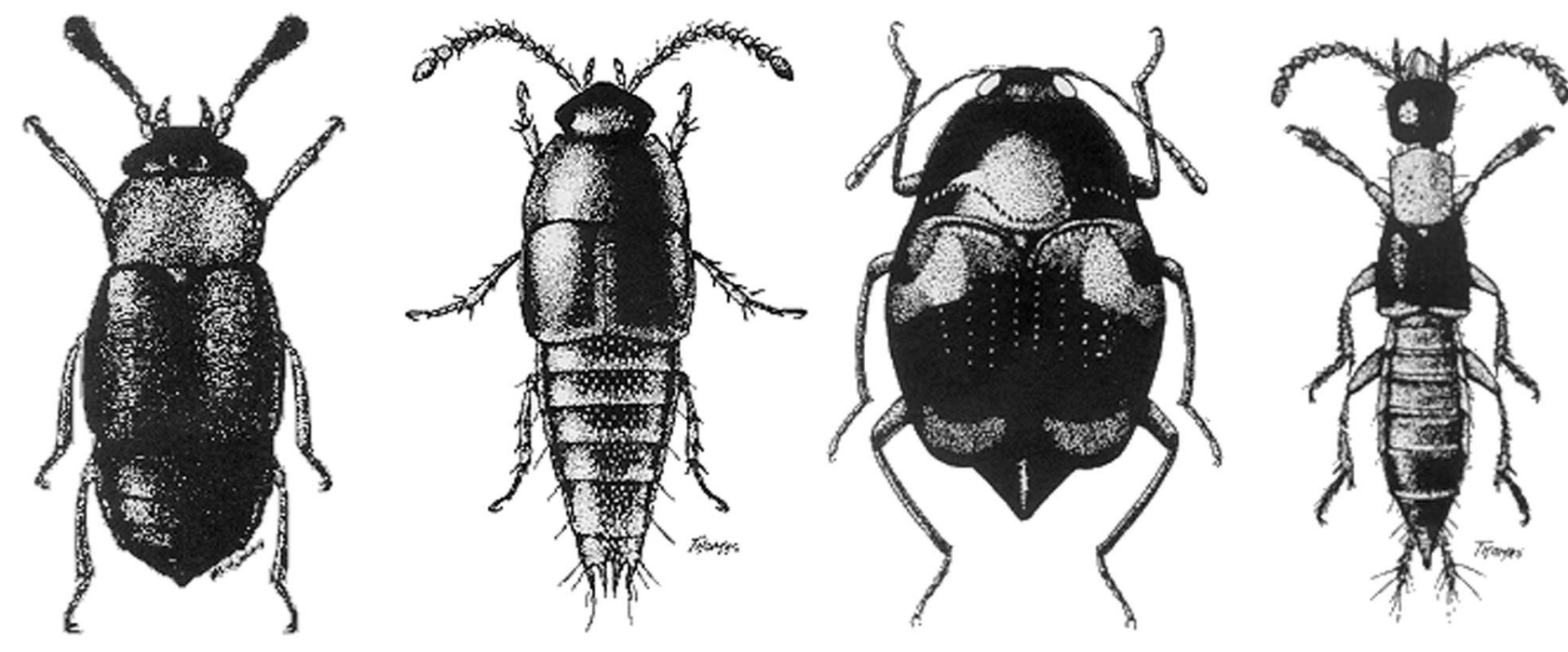

Figure 1. Representative adults of four subfamilies (left to right): Proteinus thomasi Frank (Proteininae) $1.5 \mathrm{~mm}$; Coproporus rutilus (Erichson) (Tachyporinae) $3.8 \mathrm{~mm}$; Scaphidium quadriguttatum (Say) (Scaphidinae) $4.3 \mathrm{~mm}$; Neobisnius ludicrus (Erichson) (Staphylininae) $4.1 \mathrm{~mm}$. Credits: M. C. Thomas, Division of Plant Industry

\section{Habitat and Food}

\section{Habitat}

Staphylinidae occupy almost all moist environments throughout the world. Because none of them is truly aquatic, they do not live in open waters; although winged adults may be skimmed from the sea surface far from land, their presence is due to misadventure but attests to their dispersive ability. They live in leaf litter of woodland and forest floors and grasslands. They concentrate in fallen decomposing fruits, the space under loose bark of fallen, decaying trees, drifted plant materials on banks of rivers and lakes, and dung, carrion, and nests of vertebrate animals. Several hundred species live only on seashores. Many are specialized to existence in nests of social insects. Many inhabit caves, underground burrows of vertebrate animals, and smaller soil cavities, even of burrows that they (a few of them) excavate. Many live in mushrooms. Adults and even larvae of a few are associated with living flowers. Others climb on plants, especially at night, and hunt for prey. A few seem to live with terrestrial snails. Their distribution in arid environments is restricted to moist microhabitats.

\section{Food}

A little about the feeding habits of Staphylinidae has been deduced from casual observations by many observers, and from dissections of alimentary canals and from feeding trials and examination of mouthparts by a few. Archetypal staphylinids probably were saprophagous (scavengers).

Saprophagy is still a major feeding mode in Piestinae, Osoriinae, and Proteininae, perhaps with some adaptation to mycophagy. Mycophagy has evolved in Oxyporinae, Scaphidiinae, some Tachyporinae, and a few Aleocharinae. Phytophagy has evolved in some Oxytelinae - to the point where the diet of adults and larvae of Bledius consists of diatoms, and at least one species of Apocellus has been accused of damaging flowers, one species of Carpelimus has (probably wrongly) been accused of damaging cucumbers, and one species of Osorius (Osoriinae) has been accused of damaging turf grass. Further, one species of Bledius has been blamed for its tunnelling, by which it damaged earthen banks around irrigated crops. Some Omaliinae have evolved toward eating floral parts of plants, and others toward carnivory. Saprophagy has evolved toward carnivory in other subfamilies (many Tachyporinae, most Aleocharinae, Pselaphinae, Euaesthetinae, Steninae, Paederinae, and Staphylininae), representing the bulk of species in the family, so that it may be said that most Staphylinidae 
-- tens of thousands of species -- are facultative predators. Some have specialized, for example Oligota (Aleocharinae) as predators of mites, Erichsonius (Staphylininae) as predators of soil-inhabiting nematodes, Odontolinus (Staphylininae) on mosquito larvae in water-filled flower bracts of Heliconia (Heliconiaceae), and Eulissus (Staphylininae) on adult dung-inhabiting scarab beetles. Aleochara (Aleocharinae) has evolved to become parasitoidal in fly puparia.

\section{Behavior}

\section{Presocial or Subsocial Behavior}

Such behavior is known in Bledius and Platystethus (Oxytelinae) and Eumicrota (Aleocharinae). Adults construct chambers in which they deposit and guard their eggs and young, Bledius in sandy or muddy shores, Platystethus in the dung of ungulates, and Eumicrota in mushrooms.

\section{Relationships with Social and Communal Insects}

Another dimension of social behavior has arisen in interactions with termites and ants -- thousands of species of Aleocharinae, and many species of several other subfamilies, are inquilines in the nests of these social insects, some with bizarre structural and behavioral adaptation. Emus (Staphylininae) invades bee nests in Europe, and a species of Euvira (Aleocharinae) develops in communal nests of a butterfly in Central America.

\section{Relationships with Higher Plants}

Adults of some Omaliinae are attracted to flowers, and some of these have been demonstrated to pollinate the flowers. An example is Pelecomalium testaceum (Mannerheim) (Omaliinae), which pollinates Lysichiton americanum Hultén \& St. John (Araceae) in the mountains of the Pacific coast of the USA and Canada. It is conceivable that Polyobus spp. (Aleocharinae) do the same for Espeletia spp. (Asteraceae) in the northern Andes of South America. Charoxus spp. (Aleocharinae) have a different, but yet highly specialized obligate relationship with plants -- the adults are attracted in the Neotropical region to the syconia of Ficus spp.
(Moraceae) within which they oviposit, but the adults and larvae feed on pollinating wasps (Agaonidae) of those fig flowers.

\section{Relationship with Fungi}

There are three forms of relationships with fungi. Adults and larvae of many species eat fungi. Others find prey items (fly larvae and other organisms) in fungi. A major association with fungi is that adults of many species are infected by Laboulbeniales (Ascomycetes) and some other fungi, many of which specialize at the level of host genus, tribe, or subfamily.

\section{Relationships with Decomposing Plants, Dung, and Carrion}

The frequent presence of staphylinids at decaying plant materials raises the question of whether they arrived there by random movement, and then remained there, or whether they are attracted in much the same way that adults of their prey (fly larvae, etc.) arrived there. Thus, adults and larvae of Cafius (Staphylininae) inhabit decaying brown algae (Fucales [kelp or wrack]) on sea beaches and eat fly larvae; adults and larvae of some Philonthus (Staphylininae) occur in dung of ungulates and eat fly eggs and larvae; adults of some Eulissus (Staphylininae) occur in dung of ungulates and there maim, then eat, adult scarab beetles; adults and larvae of some Belonuchus and Philothalpus (Staphylininae) occur in decaying fruits, and eat fly larvae; adults of some Platydracus (Staphylininae) occur in carrion and eat fly larvae and adults.

\section{Relationships with Terrestrial Molluscs}

Some staphylinids have been shown to feed occasionally on slugs and snails, although apparently they are not specialized to do so as are Cychrini (Coleoptera: Carabidae), nor have slugs and snails been shown to be an important part of the diet as in some Silphinae (Coleoptera: Silphidae). However, a strange, almost commensal relationship with snails has evolved in some Asian Aleocharinae such as Zyras sagax Cameron, in which the adult beetles enter the mantle cavity of Ryssota (Pulmonata:

Helicarionidae) and perhaps feed on mucus or feces of the snail. 


\section{Nests of Vertebrates}

Some staphylinid species have specialized to live in the nests of vertebrates, especially tortoises, birds, and rodents. Their prey seems to be mainly the larvae of fleas and flies. In Florida (USA) where populations of the tortoise Gopherus polyphemus (Daudin) (Testudines: Testudinidae) are declining through habitat loss and disease, populations of the staphylinid inhabitants of its nests also must be declining. Names of species of Staphylinidae found in birds' nests were compiled almost 30 years ago, but there is little information on their behavior. In central Asia, where sylvatic plague is endemic, some staphylinids are credited with suppressing flea populations, and thus help to suppress transmission of plague. Adults of Amblyopinus and close relatives (subtribe Amblyopinina of subfamily Staphylininae) occur in the fur of some rodents in Central and South America. For years they were suspected of being parasites of these rodents, and taking blood from them. Now, however, they are believed to be phoretic on the rodents, thus being transported from nest to nest. They oviposit in the nests, and larvae feed as predators there of other arthropods.

\section{Structure and Function}

\section{Secretions and Glands}

Glandular systems of Staphylinidae are mainly implicated in the production of defensive secretions, of which there is a remarkable array. However, glands of some species that are inquilines in nests of social insects produce substances that appease rather than repel the nest-builders. Further, glands of adult Stenus (Steninae) produce a surfactant, stenusin, that enables these beetles to skim over the surface of fresh water into which they have fallen, to regain dry land.

Pederin is a powerful toxin and DNA inhibitor circulating in the hemolymph of all developmental stages of some species of Paederus (Paederinae) and close allies in the subtribe Paederina. It is produced by endosymbionts in some, but not all, adult females, is transferred to eggs at oviposition, and thus to larvae and pupae. Males may obtain it by eating eggs. It is a defensive secretion active against spiders, but seems to have no insecticidal effect. It is a contender for the title of most powerful animal toxin. It produces dermatitis on human skin and severe damage to human eyes, but its therapeutic effects can be harnessed to heal chronic lesions in humans and cure cancerous growths.

\section{Pheromones}

A female sex pheromone has been identified in Aleochara curtula, but pheromones in 45,000 other species remain unidentified.

\section{Prey Capture and Pre-oral Digestion}

The mandibles are the mouthparts typically associated with prey capture by predatory adults and larvae. However, adult Stenus (Steninae) use a prey-catching apparatus in which the labium (with its palpi) can be protruded by hemolymph pressure to grip small prey such as Collembola. Oxyporinae, Steninae, Euaesthetinae, Paederinae and Staphylininae have pre-oral digestion. They use mandibles to hold their food, secrete digestive fluids, and imbibe partially-digested food. A consequence is that their digestive systems contain much liquid and few solids, so visual identification of food is difficult. Drops of anal secretions of Neotropical Leistotrophus (Staphylininae) adults placed on leaves attract their prey.

\section{Causes of Mortality}

\section{Natural Enemies}

Scattered evidence needing review suggests that spiders, various insects (including Reduviidae, Carabidae, Asilidae, Formicidae, etc.) amphibia, reptiles, birds, and bats, include Staphylinidae among their diets. Among the parasites, fungi play a major role, and hymenopterous parasitoids, nematodes, and Nemata, a relatively minor role. In temperate regions of the world as contrasted with tropical regions, staphylinids may achieve very high population levels at the soil surface; in tropical regions, at least at lower altitudes, ants are ubiquitous and staphylinids less numerous in numbers of individuals; this suggests that ants may limit population levels of staphylinids in tropical regions. 


\section{Effects of Pesticides, and Habitat Destruction}

There is a growing literature about non-target effects of chemical pesticides on Staphylinidae in agricultural crops and turf grass, to the point where Aleochara bilineata (Gyllenhal) (a demonstrably beneficial species) has become a favored test animal for the effects of insecticides, herbicides, and plant-growth regulators. Destruction of natural habitat by humans, especially in the tropics, undoubtedly contributes to the rarity of many poorly-known staphylinid species.

\section{Importance to Humans}

\section{Use in Biological Control}

Biological control practitioners have observed predation by various non-specialist Staphylinidae on fly larvae and other invertebrates and have imported various Staphylinidae into Italy, Hawaii, mainland USA, and Easter Island, to capitalize on the perceived benefits -- without evident success. Species of Belonuchus, Creophilus, Ocypus, Philonthus, Philothalpus, and Thyreocephalus (Staphylininae) and Paederus (Paederinae) have been moved. Other attempts have involved more specialist Oligota (Aleocharinae) against tetranychid mites in East Africa, and Aleochara against horn fly in mainland USA, but again with little success. Current attempts in Europe involve conservation of native staphylinids, including Tachyporus (Tachyporinae) as predators of cereal aphids, and Aleochara as predators of root maggots (including augmentative use).

\section{Other}

The importance of staphylinid predation on pests has been demonstrated repeatedly in the literature. They suppress populations of pest insects and mites in numerous crops (agricultural, horticultural and forest entomology), and of biting flies (including mosquitoes) and fleas (medical and veterinary entomology). Their presence in carrion gives them a role in forensic entomology. With one exception (Paederus and its close allies) they have trivial importance as pests; but although contact of humans with Paederus may cause dermatitis on human skin,

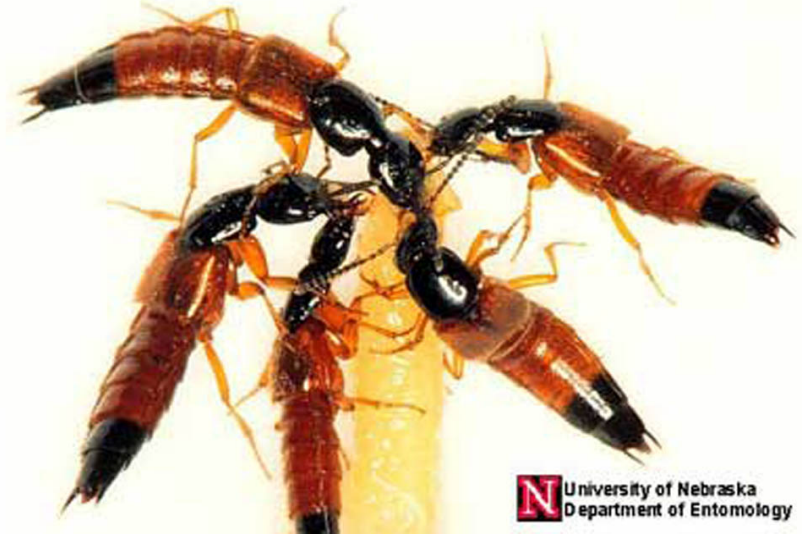

Figure 2. Rove beetles attacking a house fly maggot. Credits: Jim Kalisch and Barry Pawson, University of Nebraska-Lincoln (http://entomology.unl.edu/)

the toxin pederin may be harnessed for its therapeutic effects, and some Paederus species are valuable predators of crop pests. Finally, Staphylinidae form a substantial part of the world's biodiversity.

\section{Selected References}

Ashe JS. 1984. Major features of the evolution of relationships between gyrophaenine staphylinid beetles (Coleoptera: Staphylinidae: Aleocharinae) and fresh mushrooms, p. 227-255, in Wheeler Q, Blackwell M (eds). Fungus-insect relationships; perspectives in ecology and evolution. New York: Columbia Univ Press.

Ashe JS, Kistner DH. 1989. Larvae and adults of a new species of Euvira (Coleoptera: Staphylinidae: Aleocharinae) from nests of the communal pierid butterfly Eucheira socialis with a redescription of the genus Euvira. Sociobiology 15: 85-106.

Ashe JS, Timm RM. 1987. Activity by and activity patterns of parasitic beetles of the genus Amblyopinus (Coleoptera: Staphylinidae). Journal of Zoology (London) 212: 429-437.

Auffenberg, K. 1986. A commensal relationship between Ryssota (Pulmonata, Helicarionidae) and a beetle in the Philippines. Malacological Review 19: 113-114.

Blackwelder RE. 1936. Morphology of the coleopterous family Staphylinidae. Smithsonian Miscellaneous Collections 94(13): 1-102. 
Cheng L, Frank JH. 1993. Marine insects and their reproduction. Oceanography and Marine Biology Annual Review 31: 479-516.

Dettner K. 1987. Chemosystematics and evolution of beetle chemical defenses. Annual Review of Entomology 32: 17-48.

Dettner K. 1993. Defensive secretions and exocrine glands in free-living staphylinid beetles their bearing on phylogeny (Coleoptera: Staphylinidae). Biochemical Systematics and Ecology 21: 143-162.

Evans MEG. 1965. A comparative account of the feeding methods of the beetles Nebria brevicollis (F.) (Carabidae) and Philonthus decorus (Grav.) (Staphylinidae). Transactions of the Royal Society of Edinburgh 66: 91-109.

Evans WG. 1980. Insecta, Chilopoda, and Arachnida: insects and allies, p. 641-658, in Morris RH, Abbott DP, Haderlie EC (eds.) Intertidal invertebrates of California. Stanford, CA: Stanford Univ Press.

Fisher FW, Moore I, Legner EF, Orth RF. 1976. Ocypus olens: a predator of brown garden snail. California Agriculture 30: 20-21.

Forsyth A, Alcock J. 1990. Ambushing and prey-luring as alternative foraging tactics of the fly-catching rove beetle Leistrotrophus versicolor (Coleoptera: Staphylinidae). Journal of Insect Behavior 3: 703-718.

Frank JH. 1982. The parasites of the Staphylinidae (Coleoptera). A contribution towards an encyclopedia of the Staphylinidae. Univ Florida, Agric Exp Stns, Technical Bulletin 824: i-vii, 1-118.

Frank JH. 1991. Staphylinidae, p. 341-352, in Stehr FW (ed.) Immature Insects. Vol. 2. Dubuque, Iowa: Kendall-Hunt.

Frank JH, Bennett FD, Cromroy HL. 1992. Distribution and prey records for Oligota minuta (Coleoptera: Staphylinidae), a predator of mites. Florida Entomologist 75: 376-380.
Frank JH, Carlysle TC, Rey JR. 1986. Biogeography of the seashore Staphylinidae Cafius bistriatus and $C$. rufifrons (Insecta: Coleoptera). Florida Scientist 49: 148-161.

Frank JH, Kanamitsu K. 1987. Paederus sensu lato: Natural history and medical importance. Journal of Medical Entomology 24: 155-191.

Frank JH, Thomas MC. 1984. Cocoon-spinning and the defensive function of the median gland in larvae of Aleocharinae (Coleoptera: Staphylinidae): a review. Quaestiones Entomologicae 20: 7-23.

Frank JH, Thomas MC. 1997. A new species of Charoxus (Coleoptera: Staphylinidae) from native figs (Ficus spp.) in Florida. Journal of the New York Entomological Society 104 (996"): 70-78.

Fraser NC, Grimaldi DA, Olsen PI, Axsmith B. 1996. A Triassic Lagerstätte from eastern North America. Nature 380: 615-619.

Herman LH. 1986. Revision of Bledius. Part IV. Classification of species groups, phylogeny, natural history, and catalogue (Coleoptera, Staphylinidae, Oxytelinae). Bulletin of the American Museum of Natural History 184: 1-367.

Herman LH. 2001. Catalog of the Staphylinidae (Insecta: Coleoptera). 1758 to the end of the second millennium. Bulletin of the American Museum of Natural History 265: 1-4218 [note: this enormous scholarly work includes a bibliography to taxonomic works, together with a catalog of species belonging to most of the subfamilies (excepting only the subfamilies Aleocharinae, Paederinae, Pselaphinae, and Scaphidiinae)].

Hicks EA. 1971. Check-list and bibliography on the occurrence of insects in birds' nest. Supplement II. Iowa State Journal of Science 46: 123-338.

Hölldobler B. 1971. Communication between ants and their guests. Scientific American 224(3): 86-93.

Hu GY, Frank JH. 1995. Structural comparison of the chorion surface of five Philonthus species (Coleoptera: Staphylinidae). Proceedings of the Entomological Society of Washington 97: 582-589. 
Kellner RLL. 2001. Suppression of pederin biosynthesis through antibiotic elimination of endosymbionts in Paederus sabaeus. Journal of Insect Physiology 47: 475-483.

Kellner RLL, Dettner K. 1995. Allocation of pederin during lifetime of Paederus rove beetles (Coleoptera: Staphylinidae): Evidence for polymorphism of hemolymph toxin. Journal of Chemical Ecology 21: 1719-1733.

Kellner, RLL, Dettner K. 1996. Differential efficacy of toxic pederin in deterring potential arthropod predators of Paederus (Coleoptera: Staphylinidae) offspring. Oecologia 107: 293-300.

Kistner DH. 1982. The social insects' bestiary, p. 1-244, in Hermann HR (ed.) Social Insects. New York: Academic Press.

Klimaszewski J, Sturm H. 1991. Four new species of the oxyporine genus Polyobus Solier collected on the flower heads of some high Andean giant rosette plants (Espeletiinae: Asteraceae). Coleopterists Bulletin 45: 1-13.

Lawrence JF, Newton AF. 1995. Families and subfamilies of Coleoptera (with selected genera, notes, references and data on family-group names), $\mathrm{p}$. 779-1006, in Pakaluk J, Slipinski SA (eds.) Biology, phylogeny, and classification of Coleoptera. Warsaw: Museum i Instytut Zoologii PAN.

Leschen RAB. 1988. Natural history and immatures of Scaphisoma impunctatum (Coleoptera: Scaphidiidae). Entomological News 99: 225-232.

Leschen RAB, Allen RT. 1988. Immature stages, life histories and feeding mechanisms of three Oxyporus spp. (Coleoptera: Staphylinidae: Oxyporinae). Coleopterists Bulletin 42: 321-333.

Moore I, Legner EF. 1976. Intertidal rove beetles (Coleoptera: Staphylinidae), p. 521-552, in Cheng L (ed.) Marine insects. North Holland, New York.

Morgan AV, Morgan A. 1981. Faunal assemblages and distributional shifts of Coleoptera during the late Pleistocene in Canada and the northern United States. Canadian Entomologist 112: 1105-1128.
Naomi SI. 1987-1990. Comparative morphology of the Staphylinidae and the allied groups (Coleoptera, Staphylinoidea), Parts I-XI. Kontyû (later called Japanese Journal of Entomology) 55: 450-458, 666-675, 56: 67-77, 241-250, 506-513, 727-738, 57: 82-90, 269-277, 517-526, 720-733, 58: 16-23.

Newton AF. 1984. Mycophagy in Staphylinoidea, p. 302-353, in Wheeler Q, Blackwell $\mathrm{M}$ (eds.) Fungus-insect relationships; perspectives in ecology and evolution. New York: Columbia Univ Press.

Newton AF. 1990. Insecta: Coleoptera Staphylinidae adults and larvae, p. 1138-1174, in Dindal DL (ed.) Soil Biology Guide. New York: J Wiley and Sons.

Newton AF. 1991. Micropeplidae, Dasyceridae, Scaphidiidae, p. 334-338, and Pselaphidae, p. 353-355, in Stehr FW (ed.) Immature Insects. Vol. 2. Dubuque, Iowa: Kendall-Hunt.

Newton AF, Chandler DS. 1989. World catalog of the genera of Pselaphidae (Coleoptera). Fieldiana Zoology (N.S.) 53: 1-93.

Newton AF, Thayer MK. 1992. Current classification and family-group names in Staphyliniformia (Coleoptera). Fieldiana: Zoology (N.S.) 67: 1-92.

Newton AF, Thayer MK. 1995. Protopselaphinae new subfamily for Protopselaphus new genus from Malaysia, with a phylogenetic analysis and review of the Omaliine Group of Staphylinidae including Pselaphidae (Coleoptera), p. 219-320, in Pakaluk J, Slipinski SA (eds.) Biology, phylogeny and classification of Coleoptera: Papers celebrating the 80th birthday of Roy A. Crowson. Warsaw: Muzeum i Instytut Zoologii PAN.

Newton AF, Thayer MK, Ashe JS, Chandler DS. 2000. Staphylinidae, p. 272-418, in Arnett RH, Thomas MC (eds.) American Beetles. Vol. 1. Boca Raton, Florida: CRC Press. [note: in addition to providing keys and descriptions to genera and all higher categories of Staphylinidae of American north of Mexico, it contains an extensive bibliography]. 
Nield CE. 1976. Aspects of the biology of Staphylinus olens (Müller), Britain's largest staphylinid beetle. Ecological Entomology 1: 117-126.

Pellmyr O, Patt JM. 1986. Function of olfactory and visual stimuli in pollination of Lysichiton americanum (Araceae) by a staphylinid beetle. Madrono 33: 47-54.

Peschke K. 1978. The female sex pheromone of the staphylinid beetle Aleochara curtula. Journal of Insect Physiology 24: 197-200.

Peschke K, Fuldner, D. 1977. Übersicht und neue Untersuchungen zur Lebensweise der parasitoiden Aleocharinae (Coleoptera; Staphylinidae). Zoologische Jahrbücher für Systematik 104: 242-262.

Samsoe-Petersen L. 1996. Effects of 67 herbicides and plant growth regulators on the rove beetle Aleochara bilineata (Col.: Staphylinidae) in the laboratory. Entomophaga 40: 95-104.

Schildknecht H, Krauss D, Connert J, Essenbreis H, Orfanides N. 1975. The spreading alkaloid stenusin from the staphylinid Stenus comma (Coleoptera, Staphylinidae). Angewandte Chemie International Edition 9: 1-9.

Schmidt DA. 1996. Description of the immatures of Erichsonius alumnus Frank and E. pusio Horn (Coleoptera: Staphylinidae). Coleopterists Bulletin 50: 205-215.

Seevers CH. 1957. A monograph on the termitophilous Staphylinidae (Coleoptera). Fieldiana Zoology 40: 1-334.

Sunderland KD. 1975. The diet of some predatory arthropods in cereal crops. Journal of Applied Ecology 12: 507-515.

Thayer MK. 1985. Micralymma marinum (Stroem) in North America: biological notes and new distribution records (Coleoptera: Staphylinidae). Psyche 92: 49-56.

Tikhomirova AL. 1968. Staphylinid beetles from the Jurassic of Karatau (Coleoptera, Staphylinidae), p. 139-154, in Rohdendorf BB (ed.) Jurassic insects of Karatau. Moscow: NAUKA (in Russian).

Tod ME. 1973. Notes on beetle predators of molluscs. Entomologist 106: 196-201.

Weinreich E. 1968. Über den Klebfangapparat der Imagines von Stenus Latr. (Coleopt., Staphylinidae) mit einem Beitrag zur Kenntnis der Jugendstadien dieser Gattung. Zeitschrift für Morphologie der Tiere 62: 162-210.

Whistlecraft JW, Harris CR, Tolman JH, Tomlin AD. 1985. Mass-rearing technique for Aleochara bilineata (Coleoptera: Staphylinidae). Journal of Economic Entomology 78: 995-997.

Wilson EO. 1971. The insect societies. Cambridge, MA: Belknap Press.

Wyatt TD. 1986. How a subsocial intertidal beetle, Bledius spectabilis, prevents flushing and anoxia in its burrows. Behavioral Ecology and Sociobiology 19: 323-331.

Young OP. 1998. Observations of rove beetles' (Coleoptera: Staphylinidae) predation on dung beetles. Coleopterists Bulletin 52: 217-221. 